\title{
Factors Associated with Children's Cognitives in Daycare
}

\section{Ni Putu Andina Kluniari”, I Gusti Ayu Trisna Windiani, Putu Siadi Purniti, I Wayan Dharma Artana, I Gusti Ngurah Made Suwarba, Putu Junara Putra}

Department of Child Health, Faculty of Medicine, Udayana University, Denpasar, Indonesia

\section{Email address:}

andinakluniari@gmail.com (Ni P. A. Kluniari), trisnawindianidr@yahoo.co.id (I G. A. T. Windiani), siadi@yahoo.com (P. S. Purniti), dharma.artana@yahoo.com (I W. D. Artana), suwarbangurah@yahoo.co.id (I G. N. M. Suwarba), junara72@yahoo.com (P. J. Putra)

*Corresponding author

\section{To cite this article:}

Ni Putu Andina Kluniari, I Gusti Ayu Trisna Windiani, Putu Siadi Purniti, I Wayan Dharma Artana, I Gusti Ngurah Made Suwarba, Putu Junara Putra. Factors Associated with Children's Cognitives in Daycare. American Journal of Pediatrics. Vol. 6, No. 3, 2020 , pp. $223-227$. doi: $10.11648 /$ j.ajp.20200603.18

Received: April 12, 2020; Accepted: May 3, 2020; Published: June 4, 2020

\begin{abstract}
Cognitive development is the result of the relationship between nervous system and individual experiences to adapt to its environment. A thorough social and demographic changes lead to increased number of children receiving non-parental care. Some mothers entrust their child care in daycare. The impact of daycare service to the child's development depends on several interrelated factors, including the personality of the child, stimulation, care setting, and family condition. In daycare facilites, the children were cared non-parental or non-familial settings. Factors that may affect the child's development in a daycare are duration of care, caregiver-to-child ratio, the level of caregiver education, and child stimulation during the daycare. The aim of this study is to confirm association between the care duration, caregiver-to-child ratio, caregiver education, and daycare stimulation on child's cognitive in daycare. This was an observational analytical study with a cross-sectional design. This study was conducted at the daycare in Denpasar since July 2018 to July 2019. The child's cognitive was measured with Mullen score. A total of 80 children in 6 daycares were included. The mean Mullen score was 91.71 (SD 10.4). The bivariate analysis of caregiver education, caregiver-to-child ratio, and stimulation using independent $\mathrm{T}$ test showed significant differences. The level of caregiver education showed a mean difference of 6.3 with a p-value of 0.045 (95\% CI 0.129-12.411). The caregiver-to-child ratio showed a mean difference difference of 10.1 with a p-value of $<0.001$ (95\% CI 6.064-14.170). The multivariate analysis demonstrated that caregiver education level have a koef $B$ of 5.9 (95\% CI 0.534-11.192) with a p-value of 0.031 and caregiver-to-child ratio have a koef $B$ of 9.5 (95\% CI 5.675-13.357) with a p-value of $<0.001$ which showed significant differences. Conclusion there are significant association between caregiver education and caregiver-to-child ratio with children's cognitive in day care.
\end{abstract}

Keywords: Daycare, Cognitive, Mullen Score, Children

\section{Introduction}

A thorough social and demographic changes increased the number of children receiving non-parental care. Most mother leave their children to a nanny or a relative during worktime. Another proportion of mother entrusted their children's care in daycare. The impact of daycare service to the child's development depends on several interrelated factors, including the personality of the child, stimulation, care setting, and family condition $[1,2]$.

Developmental disorders for children aged 9-24 months in the United States are estimated at $13 \%$ [3]. Communication disorders and cognitive disorders are part of developmental disorders that occur in about $8 \%$ of children aged $2.5-5$ years [4]. A study conducted at one daycare in Denpasar showed a $13.9 \%$ incidence of suspected developmental delay [5]. The speech and language development of children aged 0-3 years in eight daycare facilities di Banjarmasin showed normal result which was appropriate for their age adjusted developmental stage [6].

Cognitive development is the result of the relationship between nervous system and individual experiences to adapt to its environment. The main factors that affect the child's Cognitive development is genetic and environmental 
factors. Genetic factors are the mainstay on which to achieve the outcome of child development. Environmental factors determine whether or not the innate potential is achieved. A favorable environment will enable the most innate potential, while the unfavorable environment will hamper it. The mother is the first and the closest environment from the fetal to adolescence stage. Hence, it is called microenvironment. In daycare facilites, the children were cared non-parental or non-familial settings [7]. Factors that may affect the child's development in a daycare are duration of care, caregiver-to-child ratio, the level of caregiver education, and child stimulation during the daycare [8].

One of the standarized tool to assess the development of children is Mullen scale. The Mullen scale was used to measure cognitive function of children aged 0-68 months [9].

Based on epidemiologic rate, the critical period of development and the necessity of children care in daycare facilities are needed for detection as well as for confirmation of the daycare's quality in regard to the duration of care, caregiver-to-child ratio, the level of caregiver education, as well as children stimulation in day care to affect the cognitive development of children

\section{Materials and Methods}

This cross-sectional study was done in day care facilities at Denpasar, Indonesia on 2018. Our study's Ethics Committee and Institutional approval were obtained from Udayana University. This study was designed to confirm the association of duration of care, caregiver-to-child ratio, caregiver education level, and children stimulation in day care on children's cognitive. The data of this study were obtained from parents' interview and measured using the Mullen scale.

The cognitive development of children was measured using the Mullen scale [8]. The day care's duration was the length of time the child is in the facility measured in hours for 1 week in the last 3 months. The caregiver-to-child ratio was a comparison between the number of children and caregivers in the facility based on the recommendations of the American Academy of Pediatrics [9]. The level of caregiver education was the highest level of formal education completed by the caregiver. Stimulation of the basic abilities of children in day care carried out by the caregiver. All activities were scheduled and implemented for 1 hour per session, 2 times a day for children in day care [3].

Minimum sample size was based on the highest samples from the four variables with a result of 76 sample. The day care facilities in Denpasar were selected using purposive sampling. The inclusion criteria are children aged 6 months to 3 years who live in Denpasar in 6 predetermined day care facilities and the parent signed the informed consent. The exclusion criteria are is preterm birth, low birth weight, children with physical limitations, suffering from chronic diseases, mayor congenital abnormalities, history of asphyxia, post intensive care and cerebral palsy. Collected data was analyzed using computer software. Analysis was done by independent T-test and logistic regression.

\section{Results}

A total of 85 children participated in the study. During the interview, 85 parents agreed to participate. Five children were excluded due to a history of low birth weight and suffering from chronic disease. A total of 80 children met the inclusion and exclusion criteria.

The characteristics of the child's age were tested for normality with the Kolmogorov-Smirnov test which showed abnormal distribution. The statistical test showed a median of 27 months with an interquartile range (IQR) (6-36). The girl was more common than the boy, with a ratio of 48 girls $(60 \%)$ to 32 boys $(40 \%)$.

Mean Mullen score of children in the daycare was tested for normality with the Kolmogorov-Smirnov test which showed a normal distribution with a mean value of 91.71, standard deviation (SD) 10.4. The Mullen score category showed that most children were in the average category at 77 children (96.2\%), and below-average at 3 children (3.8\%). The characteristics of the research subjects are shown in table 1.

Table 1. Subject characteristics.

\begin{tabular}{|c|c|}
\hline Variables & $\mathbf{n}=\mathbf{8 0}$ \\
\hline Age (months), median (min-max) & $27(6-36)$ \\
\hline Gender, n (\%) & \\
\hline Male & $32(40)$ \\
\hline Nutritional status, n (\%) & \\
\hline Malnutrition & $5(6.3)$ \\
\hline Good nutrition & $61(76.2)$ \\
\hline Overweight & $14(17.5)$ \\
\hline Exclusive breastfeeding, $\mathrm{n}(\%)$ & \\
\hline Yes & $30(37.5)$ \\
\hline No & $50(62.5)$ \\
\hline Father education level, n (\%) & \\
\hline High school & $14(17.5)$ \\
\hline College & $66(82.5)$ \\
\hline Mother education level, n (\%) & \\
\hline High school & $15(18.7)$ \\
\hline College & $65(81.3)$ \\
\hline Father's occupation, n (\%) & \\
\hline Government employees & $19(23.8)$ \\
\hline Private employee/self-employed & $61(76.2)$ \\
\hline Mother's occupation, n (\%) & \\
\hline Government employees & $16(20)$ \\
\hline Private employee/self-employed & $61(76.3)$ \\
\hline Did not work & $3(3.7)$ \\
\hline Number of children, $\mathrm{n}(\%)$ & \\
\hline$\leq 2$ & $64(80)$ \\
\hline$>2$ & $16(20)$ \\
\hline Caregiver education level, $\mathrm{n}(\%)$ & \\
\hline Did not finished high school & $13(16.3)$ \\
\hline High school & $67(83.7)$ \\
\hline Duration of care in daycare, $\mathrm{n}(\%)$ & \\
\hline$>40$ hours & $49(61.3)$ \\
\hline$\leq 40$ hours & $31(38.7)$ \\
\hline Caregiver-to-child ratio, n (\%) & \\
\hline Enough & $39(48.8)$ \\
\hline Not enough & $41(51.2)$ \\
\hline Stimulation in daycare, $\mathrm{n}(\%)$ & \\
\hline Yes & $35(43.7)$ \\
\hline No & $45(56.3)$ \\
\hline
\end{tabular}




\begin{tabular}{ll}
\hline Variables & $\mathbf{n = 8 0}$ \\
\hline Mullen score, mean, (SD) & $91.7(10.4)$ \\
Mullen score category, $\mathrm{n}(\%)$ & \\
Below average & $3(3.8)$ \\
Average & $77(96.2)$ \\
\hline
\end{tabular}

Bivariate analysis was conducted using independent T-test. Table 2 showed the comparison of Mullen score based on factors affecting children's cognitive in day care.

Table 2. The comparison of Mullen score based on factors affecting children's cognitive in day care.

\begin{tabular}{|c|c|c|c|}
\hline \multirow{2}{*}{ Variables Day care } & Mullen score & \multirow{2}{*}{$95 \%$ CI } & \multirow{2}{*}{ p-value } \\
\hline & Mean \pm SD & & \\
\hline \multicolumn{4}{|l|}{ Caregiver education level } \\
\hline High school & $92.7 \pm 9.3$ & \multirow{2}{*}{$0.129-12411$} & \multirow{2}{*}{0.045} \\
\hline Did not finished high school & $86.5 \pm 14.1$ & & \\
\hline Duration of care & & & \multirow{3}{*}{0.079} \\
\hline$<=40$ hours & $91.87 \pm 12.0$ & \multirow{2}{*}{-4513 to 5030} & \\
\hline$>40$ hours & $91.61 \pm 9.3$ & & \\
\hline Caregiver-to-child ratio & & \multirow{4}{*}{$6064-14170$} & \multirow{4}{*}{$<0.001$} \\
\hline Enough & $96.90 \pm 9.0$ & & \\
\hline Less & $86.78 \pm 9.2$ & & \\
\hline Stimulation & & & \\
\hline No & $90.91 \pm 12.1$ & \multirow{2}{*}{-6500 to 2836} & \multirow{2}{*}{0.044} \\
\hline Yes & $92.74 \pm 7.6$ & & \\
\hline
\end{tabular}

Abbreviation: $\mathrm{SD}=$ standard deviation; $\mathrm{CI}=$ confidence interval.

The multivariate analysis was conducted using multiple linear regression. The analysis was carried out on the dependent variables including the level of caregiver education and the caregiver-to-child ratio as well as controlled variables including age, sex and parental education included in the analysis as covariates. Multivariate analysis is presented in table 3 .

Table 3. The results of multiple linear regression analysis.

\begin{tabular}{llll}
\hline Variables & Koef B & $\mathbf{9 5 \%}$ CI & p-value \\
\hline Caregiver education level & 5.9 & $0.534-11.192$ & 0.031 \\
Caregiver-to-child ratio & 9.5 & $5.675-13.357$ & $<0.001$ \\
Gender & 3.7 & $-0.154-7.591$ & 0.060 \\
Age & 0.3 & $-0.510-0.081$ & 0.008 \\
\hline
\end{tabular}

\section{Discussion}

Kolmogorov-Smirnov test for normality showed that the distribution of Mullen score was normal. The bivariate analysis using independent $\mathrm{T}$ test on caregiver level of education showed a mean difference of $6.3 \pm 48$ (significant with a p-value of 0.045 (95\% CI 0.129-12.41). The level of education is among the factors which affect the quality of children care. The study by the NICHD concluded that children who receive high-quality care consistently demonstrated better cognitive and language development over the course of the first three year of life [11]. Similar, a study by Colwell et al (2013) showed a significant association $(p=0.004)$ on caregiver education level with children's cognitive outcomes based on Bayley Short Form-Research Edition (BSF-R) Mental Scale score in children in day care [12]. In a study of African descendants in America, final analysis showed that children with a caregiver in a daycare facilities with at least 14-years of education have better cognitive outcomes and language ability [13].

Children aged 6 months and over who have longer duration of care indicated better cognitive and language development than children home-cared children. It is estimated that children in day care received more diverse language pattern, more language stimulation, and more opportunities to meet with their friends to enable them to be more talkative about its desire. These children gain experience and development stimulation from a daycare setting due to intensive and strong interaction every day $[14,15]$. The duration of care in daycare within 1 week showed a mean difference of $0.3 \pm 2.7$ which was not significant with a p- value of 0.079 (95\% CI -4513-5030). Similar result were obtained in a study by the NICHD which showed the duration of care in a daycare facility is not associated with the child's cognitive. A study was conducted in US children aged 0-4.5 years who received care at daycare facility with a prospective cohort design. This study did not find any association between duration of care in day care per week with children's cognitive outcomes [16].

Another study by Cote et al (2013) showed a different result that duration of care in daycare was associated with children's cognitive outcomes. This study was a cohort design in which children received day care facilities with cognitive evalution at the age of 9 months, 3 years and 5 years [17].

Early childhood is a critical period of children's development. Studies have showed that high-quality education and early childhood care program may increase child's development. It is important to identify the environmental aspects which are the key aspect in supporting the development of children. Organizations such as the America Academy of Pediatrics (AAP) has identified indicators of a high-quality care program. The ratio of caregiver to children is a measureable structural aspect as an indicator of the quality of early childhood care. Care group is based on the needs of children in terms of fulfilling the task of child development; dividing the caregiver supervision with the caregiver-to-child ratios based on The American Academy of Pediatrics guideline [8].

Caregiver-to-child ratio showed a mean difference of $10.1 \pm 0.2$ which was significant with a p-value of $<0.001(95 \%$ CI 6064-14170). Similar result was shown in a study by Colwell et al (2013) which showed a significant association $(p=0.003)$ between the caregiver-to-child ratio and cognitive outcomes using Bayley Short Form-Research Edition (BSF-R) Mental Scale of children in day care facilities. A study of African descent in the United States in 2010 found that child in a day care facility a caregiver-to-child ratio appropriate to American Academy of Pediatrics guideline have more communication and cognitive abilities at the age of 36 months [13].

A different result found in a study in the Netherland, which showed a negative correlation between the caregiver-to-child ratio with language and cognitive development of children in day care facilities. The explanation of this could be the lack of correlation due to the limited range of groups which raised 
questions about whether there are other specific characteristics of the Dutch situation such as a high parental education. This study was conducted on 3000 children aged 0-4 years in Netherlands with a cross-sectional design [18].

Development stimulation refers to the extent to which caregivers engage in activities that are considered to improve the children development, achievement, and learning. Development stimulation by the mother at home has proven to contribute to the cognitive development of infants at the age of 15 months. Growth stimulation by caregivers are expected to positively contibute to the cognitive development of children, provided that these stimulations are in accordance with children needs [13]. In this study, stimulation of children in daycare facilities showed a mean difference of $1.8 \pm 4.6$ which was non-significant with a p-value of $0.044 \quad(95 \% \mathrm{CI}$ -6500-2836). A different result was obtained in a study by Estheret al (2010) where the results of stimulation by caregivers in daycare facilites showed a significant association $(\mathrm{B}=0.38, \mathrm{p}<0.05)$ to the children's development. This study was conducted on 64 children with a mean age of 3 months with a cohort design. The stimulation was assessed using Observational Record of the Caregiving Environment score [19].

Different results in these stimulatings factor may be due to Mullen (cognitive) score of the children in daycare facilities almost have same results (96.2\%); it is estimated that there are other factors that influence it. Family factors, such as greater stimulation at home, may also contribute to this study. This study did not sought information about the stimulation in the family. Factors of stimulation that affect children's cognitive in addition to its quantity is its quality, such as the type of stimulation provided and the quality of stimulation facilities in the form of educational game appropriate for the age and adequate room for stimulation. In this study, stimulation is only measured based on its quantity, which was the schedule and the presence of stimulation devices. This is likely to cause the results in this study; in which daycare stimulation is not related to children's cognitive.

\section{Conclusions}

There were association of caregiver-to-child ratio and caregiver education level with children cognitive development in daycare facilites. Further studies examining the other conditions or quality of daycare influences children's cognitive are needed. This is especially important in the context of governmental investments in daycare services.

\section{Disclosure}

All the authors do not have any possible conflicts of interest.

\section{Acknowledgements}

None declared.

\section{References}

[1] R. Bernal. The Effect of Maternal Employment and Child Care on Children Cognitive Development. Int. Econ. Rev 2012; 49 (suppl. 4): 1173-209.

[2] P. H. Dworkin. Perawatan anak. In: R. Behrm, R. Kliegman, editor. Nelson ilmu kesehatan anak. $20^{\text {th }}$ ed., Jakarta: EGC, 2000 pp. 138.

[3] S. A. Rosenberg, Z. Duan, and C. C. Robinson. Prevalence of developmental delays and participation in early intervention service for young children. Pediatrics. 2008; 121: pp. 1503-9.

[4] Scheffler F, Vogel D, Astern R, Burgess J, Conneally T, Salerno $\mathrm{K}$. Screening for communication and cognitive disorders in infants and toddlers. Pediatr Nurs. 2007; 33 (6): 473-80.

[5] B. Hartawan, I. G. A Windiani, Soetjiningsih. Karakteristik Tumbuh Kembang Anak di Tempat Penitipan Anak Werdhi Kumara 1, Kodya Denpasar. Sari Pediatri 2008. Jakarta, 10 (2): 134-8.

[6] G. Gunawan, Destiana, Rusmil, K. Gambaran perkembangan bicara dan bahasa anak usia 0-3 tahun. Sari Pediatri 2011, 13 (1): $21-5$.

[7] Soetjiningsih. Faktor-faktor yang Mempengaruhi Tumbuh Kembang. Soetjiningsih, I. G. Ranuh, H Suyitno, editor. Tumbuh kembang anak. $2^{\text {nd }}$ ed. Jakarta: EGC, 2012 pp. 61-72.

[8] American Academy of Pediatrics, American Public Health Association, National Resource Center for Health and Safety in Child Care and Early Education. Caring for our children: National health and safety performance standards; Guidelines for early care and education programs. $3^{\text {rd }}$ ed. Elk Grove Village: American Academy of Pediatrics. 2011. pp. 3-7.

[9] E. M. Mullen. General Administration and Scoring Procedures, dalam Mullen, E. M.: Mullen Scales of Early Learning AGS edition Manual, American Guidance Service Inc. 1995. pp. $19-31$

[10] Depdiknas. Pedoman Rintisan Program Taman Penitipan Anak. Jakarta: Ditjen PLSP Depdiknas RI; 2016.

[11] NICHD Early Child Care Research Network. Early child care and children's development prior to school entry. Am Educ Res J 2002.39 (1): 133-64.

[12] N. Colwell, R. Gordon, K. Fujimoto, R. Kaestner, S. Korenman. New evidence on the validity of the Arnett Caregiver Interaction Scale: results from the Early Childhood Longitudinal Study-Birth Cohort. Early Child Res Q 2013; 28 (2): 21-33.

[13] M. R. Burchina, J. E. Roberts, R. Riggins, S. A. Zeisel, E. Neebe, D. Bryant. Relating quality of center-based child care to early cognitive and language development longitudinally. Child Dev 2000; 71 (2). NICHD Early Child Care Research Network ans G. J. Duncan. Modeling the impacts of child care quality on children's preschool cognitive development. Child Dev. 2003; 74: 1454-75.

[14] J. Belsky. 2011. Child Care and Its Impact on Young Childrel Downloaded on December $20^{\text {th }} 2016$ Available from: URL: http://www.child-encyclopedia.com/sites/default/files/textes-e xperts/en/857/child-care-and-its-impact-on-young-children.pd f. 
[15] A. E. Guttmacher. Findings for Children up to Age $41 / 2$ Years, national institute of child Health and Human Development, pp 16-7.

[16] S. M. Cote, A. Petitclerc, O. Doyle, L. Timmins. Child Care in Infancy and Cognitive Performance Until Middle Childhood in the Millennium Cohort Study. Child Development 2013, (84): 1191-20.
[17] K. O. W. Helmerhorst, J. Riksen-Walraven, M. J. J Deynoot-Schaub, L. C. W. Tavecchio, R. Fukkink. Child Care Quality in The Netherlands Over the Years: A Closer Look. Early Education and Development 2014; 26 (1): 89-105.

[18] J. Albers, M. Esther, M. Developmental stimulation in child care centers contributes to young infants' cognitive development. Infant Behavior \& Development 2010; 33: 4018. 